\title{
The Impact of Mining Exploration on Sangaredi Community's Sustainable Development: Inhabitants Perspectives on Livelihood
}

\author{
Ibrahima Sory Madiana Camara, Jiang Deyi, Li Lin \\ School of Resources and Safety Engineering, Chongqing University, Chongqing, China \\ Email address: \\ ibrahimmadianacamara@gmail.com (I. S. M. Camara), deyij@cqu.edu.cn (Jiang Deyi), daney0803@163.com (Li Lin)
}

\section{To cite this article:}

Ibrahima Sory Madiana Camara, Jiang Deyi, Li Lin. The Impact of Mining Exploration on Sangaredi Community's Sustainable Development: Inhabitants Perspectives on Livelihood. International Journal of Mineral Processing and Extractive Metallurgy.

Vol. 6, No. 1, 2021, pp. 12-19. doi: 10.11648/j.ijmpem.20210601.13

Received: April 16, 2021; Accepted: May 4, 2021; Published: May 14, 2021

\begin{abstract}
Mining exploration has left many communities in deplorable conditions, ranging from low levels of livelihood sustenance to poor health facilities and poor road networks. This study examined the impact of mining exploration on sustainable development of a community in Guinea, West Africa. The paper reviews literature published on mining and exploration and its impact on community environments.' However, this study employed descriptive quantitative and correlational methods, which facilitated the gathering, classification and presentation of data that led to analysis, description and conclusion of the study. In this study, 300 questionnaires were distributed to community inhabitants, which enhanced the compilation of first-hand information. Data was analysed using descriptive statistics. The results disclosed numerous problems, ranging from health to education and poor road networks. It was revealed that, exploration activities have damaged lands utilised for agricultural purposes, and deposits of toxic substances have damaged soil nutrients, which caused degradation of the land tenure system. Such problems have left lands to be unproductive. Because of the foregoing problems discovered as negative impact, it is fitting for government and mining corporations to pay considerable attention to Sangaredi community and address such problems. This study identified issues bothering Sangaredi and other communities where mining explorations are conducted. It descriptively explained issues of exploration and established the negative impact mining activities have caused in the community. However, such impact adversely affects the community at large. In addition, academics and mining consultants will use this information as a source for further investigation on the subject matter.
\end{abstract}

Keywords: Mining Exploration, Sangaredi Community, Sustainable Development, Livelihood

\section{Introduction}

Sustainable development has been a goal many nations have been relentlessly working towards. Although affected by many challenges, achieving sustainable development requires strategies on how to manage national resources judiciously to maintain a level of economic activity in the competitive global landscape. Mining industries in developing countries have contributed towards economic growth. However, exploration activity has damaged some communities' environment and has made some lands infertile because of the methods used in the exploration activities'. This study determines to examine mining exploration conducted by Guinea Bauxite Company (GBC), which operates in the interiors of the country called Sangaredi. The company focuses on exploration of mineral resources with emphasis on bauxite mining. Citizens of Guinea and inhabitants of communities, where exploration exercises are conducted have raised concerns about the growth and sustainability of their communities and such concerns have attracted many scholars and mining practitioners to examine the effects exploration has had on those communities. Similar researches carried out by mining specialist establish the contributions made by the company towards the country's economy. However, quantum of effects on its exploration exercises are also established and it is upon this backdrop that this study emanated from to assess and discover the impact the company's exploration exercises has had on Sangaredi community's sustainable development. 
This concept of sustainable development is subject to economic development, which encompasses social and ecological elements that determine requirements of contemporary issues capable of influencing contributions of existing philosophies to address concerns of forthcoming generations [2-5]. Taking these into consideration, the various economic sectors still remains to be seen materialize. The mining industry, like other sectors, is no exception to this practice. All that we have witnessed since the last decade of the twentieth century shows multiplication of large-scale mining projects that meet the growing global demand for minerals without considering impact relating to the multiple brutal transformations of the landscapes and the living environment of local communities [6-9]. In this perspective, reorientation is imperative for companies, whose activities are often accused of being responsible for serious degradations of the environment. Sustainable development becomes a matter of image, a strategic option, which must reconcile economic growth and appropriate development. Without entering the dialectic of precedence between economic growth and development, sustainable development needs to have a holistic vision of development based on the exploitation of mineral resources [10-14]. However, since mining is an activity whose very nature is fundamentally linked to the concept of risk, the identification, knowledge, prevention and management of these risks is of paramount importance. Any underestimation of these risks can have impacts on numerous sectors.

Faced with this proven constraint of mining activity, environmental assessment, measures and predict various dimensions in the mining process, which anticipate future solutions in mining activities. However, this objective is far from being achieved, since inadequacies are identified in management plans on environmental and social issues in many African mining countries [15-17, 29]. The reasons for these failures are inherent in mining companies, and this is why mining is often associated with many cases of negative externalities, each of which party blames government intervention [30-32]. Mining companies criticize factors endangering their activities, which includes corruption of government officials, and unethical practices exhibited by governance in these countries rich in mineral resources [1833]. Many government point fingers at mining companies that they take advantage of their political instability to arrogate leonine contracts. However, both sides (government and mining companies), should agree on the relationship between the efficiency of the mining activity and the type of governance put in place, to ensure regulation of mining activities [19, 20, 34].

The management of the main economic sectors of the country, particularly the mining sector is the subject of all criticism. Questions come from all categories such as unions, associations, nongovernmental organisations (NGOs), leaders and political actors. In this discontent widespread, many causes are singled out which identify predatory mining companies, corrupt managers, looted resources etc. In this regard, it is difficult to distinguish causes from consequences and culprits from accomplices since the opportunity to promote sustainable development is constructively linked to exploitation of mineral resources [21, 22, 35, 24]. Indeed, the choice to promote the development of a country from mining involves many factors such as sustainability, creation of added value role of different actors, multiple externalities, etc. Mining for development must obey certain fundamental principles governing mining operations including transparency and access to information. In this perspective, the role of a nation is to ensure adherence to certain standards and compliance to legislative principles regarding mining operations [39-41].

Mining is a lever for economic development and can be triggered for the general growth of the country. Despite the immense social and environmental impacts associated with it, the approach of the development through the exploitation of mineral resources is justified by arguments that this constitutes the economic point of view, a natural capital whose extraction produces wealth which can be consumed or reinvested in the production of other types of capital $[1,25$, 26]. In addition, from a social point of view, transnational companies promote training and education, to increase countries' human capital. They offer huge training and employment opportunities for indigenous people. For all these reasons, mineral resources would therefore constitute an opportunity for countries development [27-28]. Generally speaking, for the proponents of this approach, the development of a country is possible from the exploitation of its mineral resources. Finally, between these two distinct approaches, there is a more centrist approach that can contribute towards a country's development process. For this approach, if economic development is possible through the development of mineral resources, this possibility is often accompanied by the establishment of an appropriate governance mechanism [43, 36, 38, 42].

\section{Literature Review}

\subsection{Environmental and Social Impacts of Mining Exploration}

Environmental Impact Assessment programmes for mining projects often underestimate the potential health risks of mining projects. Hazardous substances and wastes deposits in water and soil can have serious consequences on public health. Health is defined as the absence of ill-health and complete social, physical and mental well-being of a person $[13,2,9]$. The Hazardous substances includes all substances, which may be harmful to the population and / or the environment. Due to the quantum concentration of physical, chemical or infectious characteristics, hazardous substances can lead to escalation of mortality and increases devastating illnesses [7-14].

It also constitute potential and substantial risk to the populace or environmental degradation if improperly processed, stored, transported, disposed of or otherwise managed. Many health problems that are linked to mining activities include water contamination, which is polluted by 
surface and ground water, metals and elements, microbiological contamination by sewage and waste in campgrounds and residential areas of mining workers $[3,8$, $12,4]$. Air exposure also has high absorptions of mercury and cadmium, sulphur dioxide particles and heavy metals. However, the deposit of toxic elements from atmospheric emissions [5-11] also affects soil.

Mining activities can suddenly affect the standard of living and physical well-being including social and mental concerns of local communities. The improvised mining towns and camps often threaten food availability and security, thus increasing the risk of malnutrition [6-10]. Mining has indirect consequences on health, which includes the increased occurrence of chronic bronchitis, asthma, tuberculosis, and gastrointestinal diseases. During exploration, air emissions occur at every level of mining exercise, which affects development, construction and operational activities [20,31, 16]. Large mining operations have the tendency to contribute meaningfully to air pollution, especially in the operational phase. Activities during bauxite extraction, processing, handling and transporting, depend on the equipment, generators, processes and materials which generate dangerous air pollutants such as matter, heavy metals, carbon monoxide, sulphur dioxide and nitrogen oxides [17, 18].

\subsection{Sustainable Development and Mining}

Sustainable development in mining identifies numerous methodologies, analyse the scope and limits in relation to the role mineral resources play in the development of a country. The contribution of mineral resource towards the growth of a country raises many questions and is the subject of a rich and varied literature that can be classified into two distinct approaches [15, 34, 32, 17]. The first approach states that wealth in mineral resources is not necessarily synonymous with economic development. Several reviewed literatures supports this approach and emphasised that, mining poses enormous risks to countries rich in mineral resources $[29,30$, 22]. The effects are destabilization of the social values of local population, disruption of natural ecological balances and strengthening of the country's dependence on the export of minerals [25]. Thus, the establishment of mining companies often leads to the arrival of new people, loss of accorded privileges to natives. Losing control of a territory once acknowledged as inheritance could definitely nurture conflict. Industrial mining activity produces externalities for the host environment as such mining is associated with multiple negative externalities it generates [23, 44, 21]. The second approach notes that mining is a lever of economic development and can be triggered for the overall growth of the country's economy.

Despite the immense social and environmental impacts associated with it, development through exploitation of mineral resources is justified by arguments that constitute an economic point of view, a natural capital whose extraction produces wealth that can be consumed or reinvested in the production of other types of capital [40, 35, 26, 39]. In addition, from a social point of view, transnational companies promote training and education, to increase countries human capital through enormous training and employment opportunities for indigenous people. In consideration to aforementioned reasons, mineral resources would therefore constitute an opportunity for countries that embark on mining operations to support this approach as it leads to the development of a country's mineral resources [1, 24, 41, 9].

\subsection{Mining Exploration and Community Livelihood}

When mining activities are not properly managed, the consequences will be degradation of soil, water, biodiversity and deforestation, which has diverse undesirable effects on the livelihood of the local population. Mining exploration's negligence in the control of contamination, consequently affect other economic activities including agricultural and fishing exercises [14, 2, 13]. The situation principally affects communities where exploration operations are administered in villages occupied by historically marginalized populations and victims of discrimination. Promoters of mining projects should guarantee adherence to fundamental rights of affected people and communities and ensures that such rights are not violated but respected [27, 12,7]. These rights encompass control and utilisation of land, the right to safe drinking water and the right to livelihood. These rights can be enshrined in national laws, and expressed through a range of international instruments [8-3]. All groups are equal under the law, and the interests of groups that are more vulnerable (low income and marginalized groups) must be identified and protected [4-28]. Mining exploration can contaminate soils on large areas where agricultural activities of a mining project can be affected. Mining operations regularly modify the surrounding landscape by exposing soils that were previously intact $[6,16$, 20]. Erosion expose soils, mined ores, slag heaps and fine materials in the waste heaps of rocks, which lead to substantial sediment loads in the exterior of waters and water drainage routes. In addition, hazardous materials and deposits of contaminated substances thrashed can lead to soil contamination $[31,5,11]$.

\section{Methods}

\subsection{Research Design}

Examining the effects of exploration requires suitable methods of data collection to ascertain development in the conduct of this study. The conduct of an investigation requires a unique research design, which shows a progressive path towards the achievement of research objectives. The absence of a constructive research design creates pursuits of diverse objectives, which does not institute a sense of direction that is followed to establish satisfactory and meaningful conclusion. However, this study employed descriptive quantitative and correlational research methods, which is deemed suitable for the process since primary data obtain, will address concerns of the subject matter in a scientific fashion and will enable readers and researchers to see the meaningfulness of the study. 


\subsection{Study Area}

This study was conducted in the interiors of Guinea Conakry, specifically in the Sangaredi Community where numerous mining activities commence operations. The sample frame of this study is the Sangaredi Community and the sample units are the inhabitants of the said community. Such community have endured tremendous happenings in the mining and explorations of bauxite and that has led to several constrains of inhabitants livelihood. This area was selected as the study sample frame because the community host quantum of mining activities that has contributed towards the development of the country's economy and has created devastating consequences towards the growth and sustainability of the community.

\subsection{Sampling of Respondents}

This study used simple random sampling to select different categories of people that produces comprehensive information, which leads to objective analysis and discussion. This method enabled us to obtain a sample size of three hundred (300) participants, which served as representative sample for the research process. The sample size is segmented into the following categories: 150 of the participants are male whilst also 150 are female. However, such community houses a greater number of female residents.

\subsection{Research Instrument}

Every research that focuses in obtaining first-hand information requires the collection of information either through observation, discussion or with the aid of a questionnaire. This study obtained first-hand information through administering questionnaires to target population. However, 400 questionnaires were distributed but 300 were retrieved, filled with relevant information availed by respondents. Retrieved questionnaires were sorted out accordingly and raw data was imputed into SPSS for analysis and description of information submitted by respondents. This study developed a questionnaire using the Linkert scale system of obtaining information, which includes the following: 5=Strongly Agree, 4=Agree, 3=Neutral, $2=$ Disagree, $1=$ Strongly Disagree. Description of contents of literature review emanated from various researches conducted by numerous academic and scientific practitioners. The aforesaid is classified as follows: Environmental and Social Impacts of Mining and Exploration was adopted from [9, 13, 2], Sustainable Development and Mining was obtained from [32, 15, 19, 34], whereas Mining Exploration and Community Livelihood was extracted from the discoveries of $[2,13,14]$.

\section{Results and Discussion}

Assessing the impact of mining and exploration on communities' sustenance engulfs quantum of considerable issues that necessitate the growth of such communities. As this study investigates the impact of mining exploration on Sangaredi community, it engaged inhabitants of such community to ascertain constraints of being in a community where exploration is intensive. However, 300 inhabitants participated in the survey with a description of 150 male with $50 \%$ and 150 female with $50 \%$. The age range of respondents is classified as 18-25, 26-35, 36-45 and 46+. Respondents' designations are outlined as follows: Businessperson, farmer, technician and unskilled. Respondents stated that there are unsatisfactory changes in nature and animals because of exploration exercises. They further expressed that, their cultivation system have changed because of afore expressed. The intensity of mining operations has also affected communities' social relationships, which has had serious effects on communities' income generation. Respondents further stated that, several health problems encountered is because of unceasing exploration exercises, which pollutes the air and affect respiratory situations. Power relations have also been affected since communities cannot converge frequently to discuss issues relating to community governance. Greater percentage of respondents expressed that, their living conditions are unsatisfactory since their activities are no longer effective as they use to be; as agriculture, which is inhabitants' greatest concentration of livelihood and sustenance is affected by degradation and soil pollution. In addition, respondents emphatically stated that, decisions about the use of land are made by authorities in the community, which limits cultivation exercises. However, respondents registered unsatisfactory medical facilities. They mentioned that, accessing good medical facility is a great challenge and even though several concerns have been forwarded to the required authorities, there are no signs of improvement. As a result of the foregoing responses from participants in the field, it is established that the operations of the said mining company negatively affect environmental activities and adversely affect the social engagements of inhabitants. Intense mining exploration has left the community with several problems that have deprived famers form cultivating their crops since the lands are polluted by toxic elements. In addition, constant exploration has led to air pollution that has caused many illnesses. In consideration of the above facts, it is clearly indicated that the mining activities have created negative environmental and social impact in the said community. This result is supported by studies conducted by different researchers such as: Brown, Carvalho, Jackson et al \& Jain et al on environmental and social impact of mining exercises $[3,6,17,18]$. However, this segment present unique element that is not evident in previous studies. 
Table 1. Descriptive Statistics on the distribution of respondent regarding environmental and social impacts of mining and exploration.

\begin{tabular}{|c|c|c|c|c|c|c|c|c|c|c|c|c|}
\hline & $\mathbf{N}$ & Range & Minimum & Maximum & Mean & & Std. Deviation & Variance & Skewness & & Kurtosis & \\
\hline & Statistic & Statistic & Statistic & Statistic & Statistic & $\begin{array}{l}\text { Std. } \\
\text { Error }\end{array}$ & Statistic & Statistic & Statistic & $\begin{array}{l}\text { Std. } \\
\text { Error }\end{array}$ & Statistic & $\begin{array}{l}\text { Std. } \\
\text { Error }\end{array}$ \\
\hline TUCRNA & 300 & 2 & 1 & 3 & 2.33 & .043 & .747 & .557 & -.629 & .141 & -.956 & .281 \\
\hline YCC & 300 & 2 & 1 & 3 & 2.47 & .039 & .671 & .450 & -.880 & .141 & -.384 & .281 \\
\hline TCSRV & 300 & 2 & 1 & 3 & 2.33 & .043 & .747 & .557 & -.629 & .141 & -.956 & .281 \\
\hline TESC & 300 & 2 & 1 & 3 & 2.23 & .044 & .762 & .581 & -.421 & .141 & -1.169 & .281 \\
\hline THPEE & 300 & 2 & 1 & 3 & 2.47 & .039 & .671 & .450 & -.880 & .141 & -.384 & .281 \\
\hline EECCPRV & 300 & 2 & 1 & 3 & 2.33 & .040 & .700 & .491 & -.566 & .141 & -.824 & .281 \\
\hline LCU & 300 & 1 & 1 & 2 & 1.50 & .029 & .501 & .251 & .000 & .141 & -2.013 & .281 \\
\hline AAHAE & 300 & 2 & 1 & 3 & 2.37 & .038 & .659 & .434 & -.559 & .141 & -.680 & .281 \\
\hline ADLV & 300 & 2 & 1 & 3 & 2.33 & .040 & .700 & .491 & -.566 & .141 & -.824 & .281 \\
\hline MFC & 300 & 1 & 1 & 2 & 1.53 & .029 & .500 & .250 & -.134 & .141 & -1.995 & .281 \\
\hline $\begin{array}{l}\text { Valid N } \\
\text { (listwise) }\end{array}$ & 300 & & & & & & & & & & & \\
\hline
\end{tabular}

Table 2. Descriptive Statistics on the distribution of respondent concerning sustainable development and mining.

\begin{tabular}{|c|c|c|c|c|c|c|c|c|c|c|c|c|}
\hline & $\mathbf{N}$ & Range & Minimum & Maximum & Mean & & Std. Deviation & Variance & Skewness & & Kurtosis & \\
\hline & Statistic & Statistic & Statistic & Statistic & Statistic & Std. Error & Statistic & Statistic & Statistic & $\begin{array}{l}\text { Std. } \\
\text { Error }\end{array}$ & Statistic & $\begin{array}{l}\text { Std. } \\
\text { Error }\end{array}$ \\
\hline MAINA & 300 & 2 & 1 & 3 & 2.37 & .038 & .659 & .434 & -.559 & .141 & -.680 & .281 \\
\hline IGCAA & 300 & 2 & 1 & 3 & 2.33 & .040 & .700 & .491 & -.566 & .141 & -.824 & .281 \\
\hline MACSR & 300 & 2 & 1 & 3 & 2.40 & .038 & .664 & .441 & -.661 & .141 & -.618 & .281 \\
\hline MEILES & 300 & 2 & 1 & 3 & 2.27 & .042 & .728 & .531 & -.458 & .141 & -1.008 & .281 \\
\hline MECHRP & 300 & 1 & 1 & 2 & 1.53 & .029 & .500 & .250 & -.134 & .141 & -1.995 & .281 \\
\hline EDNSD & 300 & 2 & 1 & 3 & 2.37 & .038 & .659 & .434 & -.559 & .141 & -.680 & .281 \\
\hline SDDDFM & 300 & 2 & 1 & 3 & 2.37 & .038 & .659 & .434 & -.559 & .141 & -.680 & .281 \\
\hline ASDAE & 300 & 2 & 1 & 3 & 2.37 & .038 & .659 & .434 & -.559 & .141 & -.680 & .281 \\
\hline RHRSD & 300 & 1 & 1 & 2 & 1.53 & .029 & .500 & .250 & -.134 & .141 & -1.995 & .281 \\
\hline IPHCSD & 300 & 1 & 1 & 2 & 1.57 & .029 & .496 & .246 & -.270 & .141 & -1.940 & .281 \\
\hline $\begin{array}{l}\text { Valid N } \\
\text { (listwise) }\end{array}$ & 300 & & & & & & & & & & & \\
\hline
\end{tabular}

Achieving Sustainable development in communities that are ravaged by continuous exploration exercises is an enormous challenge. Inhabitants in Sangaredi community are concern about the sustainability of their livelihood and the consequence of intensive exploration on future generational activities. Respondents noted that, mining activities affects the living conditions of their animals and cultivation of rice, which support household income generation. Social interactions, which necessitate harmonious relationships amongst inhabitants in the community is been restrained by mining activities. Respondents mentioned that, local economic situation is greatly affected by mining operations because sources of income generation are interrupted by explorations. However, the continuous health related problems reported by inhabitants is caused by air pollution, which is triggered by mining explorations. Respondents registered significant concerns that, economic development is a necessity for sustainable development and that; sustainable development demands a fair distribution of food and medical care. Achieving sustainable development is challenging but requires consciousness about livelihood issues. In this regard, respondents accentuated that, to achieve sustainable development, inhabitants of Sangaredi community must have access to good education, which may serve as future source of sustainable growth. Another principal concern expressed by respondents is the issue of human rights. They noted that, sustainable development can never be achieved if people's rights are not respected and protected. They added that, improving health facilities in the Sangaredi community would contribute towards sustainable development. The aforementioned facts about sustainable development have been extensively supported by quantum researches conducted on mining and sustainability. Such studies laid emphasis on upholding human rights and organisations commitment on corporate social responsibility. The different research results emphasised continuous community sensitisation on several issues of development. This study has also discovered numerous constraints encountered by inhabitants of Sangaredi community. It however disclosed that, with the numerous problems outlined by respondents of Sangaredi Community, sustainable development cannot be achieved since key elements that enhances sustainability is neglected. In addition. Respondents' views have provided facts about this study's focus on sustainable livelihood. In consideration to facts obtained from survey, this result has considerable significance to investigations conducted by Gordon and Graedel, Rosemarin \& Scholz et al [13, 29, 32] in their quest to discover the dictates of sustainable development in mining operations. Nevertheless, results presented in this segment shows distinctive significance that previous investigations did not establish. 
Table 3. Descriptive Statistics on the distribution of respondent on mining exploration and community livelihood.

\begin{tabular}{|c|c|c|c|c|c|c|c|c|c|c|c|c|}
\hline & $\mathbf{N}$ & Range & Minimum & Maximum & Mean & & Std. Deviation & Variance & Skewness & & Kurtosis & \\
\hline & Statistic & Statistic & Statistic & Statistic & Statistic & $\begin{array}{l}\text { Std. } \\
\text { Error }\end{array}$ & Statistic & Statistic & Statistic & $\begin{array}{l}\text { Std. } \\
\text { Error }\end{array}$ & Statistic & $\begin{array}{l}\text { Std. } \\
\text { Error }\end{array}$ \\
\hline PPDIBO & 300 & 2 & 1 & 3 & 2.20 & .046 & .793 & .629 & -.373 & .141 & -1.317 & .281 \\
\hline PPIIPF & 300 & 2 & 1 & 3 & 2.27 & .042 & .728 & .531 & -.458 & .141 & -1.008 & .281 \\
\hline PIPDLA & 300 & 2 & 1 & 3 & 2.23 & .044 & .762 & .581 & -.421 & .141 & -1.169 & .281 \\
\hline SLAIR & 300 & 2 & 1 & 3 & 2.17 & .045 & .779 & .608 & -.300 & .141 & -1.296 & .281 \\
\hline PFEIF & 300 & 1 & 1 & 2 & 1.53 & .029 & .500 & .250 & -.134 & .141 & -1.995 & .281 \\
\hline GHL & 300 & 2 & 1 & 3 & 2.13 & .047 & .807 & .651 & -.247 & .141 & -1.423 & .281 \\
\hline VEDAMF & 300 & 2 & 1 & 3 & 2.37 & .038 & .659 & .434 & -.559 & .141 & -.680 & .281 \\
\hline FSIMLN & 300 & 2 & 1 & 3 & 1.83 & .050 & .861 & .741 & .328 & .141 & -1.576 & .281 \\
\hline FCIIL & 300 & 2 & 1 & 3 & 2.40 & .041 & .713 & .508 & -.758 & .141 & -.694 & .281 \\
\hline $\begin{array}{l}\text { Valid N } \\
\text { (listwise) }\end{array}$ & 300 & & & & & & & & & & & \\
\hline
\end{tabular}

Maintaining sustainable livelihood is saturated by huge challenges since there are different elements that address such criticalities. In this regard, inhabitants of Sangaredi community demonstrated concerns about how mining exploration affects their livelihood. A larger percentage of respondents mentioned that, the project provides income/cash benefit opportunities to inhabitants of Sangaredi community. However, respondents emphasised that mining corporations provide vital information about protecting the forests, which prevents deforestation and contribute towards community development. Concerning livelihood, respondents indicated that, mining institutions have helped to improve participation in decision making on livelihood issues. Respondents also attested that their skills in livelihood issues have improved over the past 2-3 years because of effective tutoring programmes conducted by mining corporations. Respondents also indicated that protecting the forest ecosystem is a significant endeavour for them and their community. Nevertheless, the unavailability of numerous sources of income led to deforestation, which also affects community development. In this regard, respondents mentioned that, they are willing to stop deforestation if provided with necessities that sustain their family livelihood. Regarding happiness about living conditions and other community issues, some respondents mentioned that their living conditions are unsatisfactory whereas others stated that there conditions have been pleasant over the past 2-3 years. Accessing business centres to purchase items for domestic and other use is a big challenge, since the road network is very poor and distances between communities and market centres is long. Concerning the sufficiency of income to address basic family needs, major percentage emphatically stated that, their families do not have sufficient income to maintain basic family needs. Regarding coping mechanisms with insufficient income, greater percentage of respondents demonstrated that they cope with the insufficient income they have, since there is no alternative source to address other commitments. Regarding infrastructural support, respondents mentioned that they benefit from infrastructural supports provided by mining corporations in Sangaredi community. Facts presented in this segment shows companies commitment on their social responsibility and also disclosed negative aspects of exploration on community livelihood. With the foregoing, it is evident that, livelihood situation of Sangaredi community is deplorable and requires government and corporations effort to address unpleasant situations of human living. The foregoing facts have emphasised concerns about livelihood, which studies such as Vaccari, Loureiro et al \& Jain et al supported. Nevertheless, the result in this section established specific elements about livelihood, which previous studies did not address $[39,21,18]$. As a result, facts derived from this section shows distinct significance

Table 4. Correlations on the relationship between sustainable development and community livelihood.

\begin{tabular}{|c|c|c|c|c|c|c|c|c|c|c|}
\hline & 1 & 2 & 3 & 4 & 5 & 6 & 7 & 8 & 9 & 10 \\
\hline MACSR & 1.000 & & & & & & & & & \\
\hline MEILES & .884 & 1.000 & & & & & & & & \\
\hline EDNSD & .963 & .911 & 1.000 & & & & & & & \\
\hline ASDAE & .963 & .911 & 1.000 & 1.000 & & & & & & \\
\hline RHRSD & .866 & .802 & .827 & .827 & 1.000 & & & & & \\
\hline IPHCSD & .832 & .783 & .795 & .795 & .935 & 1.000 & & & & \\
\hline PPDIBO & .863 & .950 & .884 & .884 & .827 & .816 & 1.000 & & & \\
\hline PPIIPF & .884 & 1.000 & .911 & .911 & .802 & .783 & .950 & 1.000 & & \\
\hline PIPDLA & .872 & .972 & .895 & .895 & .814 & .799 & .974 & .972 & 1.000 & \\
\hline PFEIF & .866 & .802 & .827 & .827 & 1.000 & .935 & .827 & .802 & .814 & 1.000 \\
\hline
\end{tabular}

Correlations between sustainable development and community livelihood show positive significant relationship between the two components. However, respondents noted that, because of changes in the land tenure system by mining operations, social relationships will definite experience changes as well, which consequently affect local economic situation since harmonious relationship is deprived by intense exploration exercises. Respondents highlighted that, since 
income generation facilitate the improvement of inhabitants living conditions, they believe that economic development is necessary for sustainable development. However, respondents accentuated that, achieving sustainably development encompasses the provision of quality education for Sangaredi community inhabitants as it creates awareness about community development and livelihood issues. Respondents noted that, corporations' commitment on their corporate social responsibility would help to improve inhabitants' health status through the provision of good medical facilities. In addition, because of upholding human rights, respondents emphatically stated that sustainable development would definitely be enhanced. It is also noted that, if community people are provided with adequate information about deforestation and cash benefit opportunities; they will deceased from hewing trees that protect the surface of the land, as their livelihood will no longer be on deforestation, since protecting the forest is significant for them and their families. Respondents mentioned that improving their understanding about decision making regarding livelihood issues would minimize their suffering and dependence on others. Having critically examined the relationship between sustainable development and livelihood, it is believed that both work corporately to improve Sangaredi community.

\section{Conclusions}

This study has carefully investigated the impact of mining exploration on Sangaredi community's sustainable development; with inhabitants' perspectives on livelihood issues. Engaging in such endeavour is quite challenging, particularly gathering primary information from a community that is highly stress about living conditions. However, this study critically reviewed secondary information published about mining exploration and livelihood issues. It consulted books, magazines, journal articles and other relevant references that contributed to the development of pieces of literature which identified gaps addressed by this study. This study employed descriptive quantitative survey and correlational methods; which facilitated the gathering, classification and presentation of data that led to the analysis, description and conclusion of the subject been studied. However, 300 questionnaires were distributed to inhabitants of Sangaredi community, which facilitated the gathering of first-hand information that enhanced the completion of this study. Primary data obtained from survey was analysed using descriptive statistics and correlation with the aid of SPSS. Analysed facts disclosed that, operations of mining companies have damaged communities in several forms. Agricultural activities have been restrained because of degradation and the deposits of toxic elements on the surface of the land. In addition, processed data disclosed that social relationships are constrained, health conditions are deplorable and accessibility to quality education is a big challenge. Other concerns expressed by the community are, accessibility to shopping centres is constrained by poor road network and also violation of human rights is evident. In addition, since inhabitants cannot engage fully in their income generation activities, their living conditions are frustrating as there are no alternative sources of income for their livelihood. This makes families to cope with insufficient income for their livelihood, which consequently affect their health status and development agendas. In consideration of the above facts, it is evident that Sangaredi community is constrained because of aforementioned discovered facts about their standard of living. This study has discovered some facts about mining exploration regarding Sangaredi community and has established issues of concern that both government and corporation could discuss and find solution. However, this investigation will serve as noteworthy information to mining companies in Sangaredi and other communities in Guinea. Achieving results of this study was facilitated by a limited sample size of 300 respondents and a sample frame of one community; however, future endeavours will consider an expansion through increasing the sample size and frame or probably deal with specific issues dealt with in this study.

\section{References}

[1] Basov, V. (2015). True giants of mining: World's top 10 iron ore mines. Available at http://www.mining.com/author/vladimirbasov/ (accessed 1 March 2017).

[2] Bebbington, A., and Malerba, D. (2019). Water and mining conflicts in Peru. Mt. Res. Dev. 28: 190-195.

[3] Batool, S. A. (2014). World on the edge: how to prevent environmental and economic collapse. W. W. Norton \& Company, New York, London. 240 pp.

[4] Biermann, F. (2017). Livelihoods, mining and peasant protests in the Peruvian Andes. J. Lat. Am. Geogr. 1: 1-19.

[5] Cao, J. G.; Emission. (2017). 210Pb and 210Po in sediments and suspended matter in the Tagus estuary, Portugal. Local enhancement of natural levels by wastes from phosphate ore processing industry. Sci. Total Environ. 159: 201-214.

[6] Carvalho, F. P. (2011). Environmental radioactive impact associated to uranium production. Am. J. Environ Sci. 7: 547553.

[7] Chang, S. E., J. Stone, K. Demes, and M. Piscitelli. (2014). Consequences of oil spills: a review and framework for informing planning. Ecol. Soc. 19: 26.

[8] Cordell, D., J.-O. Drangert, and Wiedmann, T. (2018). The story of phosphorus: global food security and food for thought. Glob. Environ. Change 19: 292-305.

[9] Fernandez-Lozano, J., G. Gutierrez-Alonsoa, and M. A. Fernandez-Moran. (2015). Using airborne LiDAR sensing technology and aerial orthoimages to unravel roman water supply systems and gold works in NW Spain (Eria valley, León). J. Archaeol. Sci. 53: 356-373. https://doi.org/10.1016/j.jas.2014.11.003. 
[10] Flor, P. (2014). Mining and economic development in Peru. ReVista, Harvard Review of Latin America, Harvard University, Rockfeller Centre. Available at http://revista.drclas.harvard.edu/book/mining-and-economicdevelopment-peru.

[11] Freese, B. (2004). Coal: a Human History. Penguin Books, London. $137 \mathrm{pp}$.

[12] Gilbert, N. (2009). The Disappearing Nutrient. Nature 461: 716-718.

[13] Gordon, R. B., M. Bertram, and Calnek-Sugin, T. (2017. Metal stocks and sustainability. Proc. Natl. Acad. Sci. 103: 1209-1214.

[14] Heckenmüller, M., D. Narita, and G Cornell, S. E. (2017). Global availability of phosphorus and its implications for global food supply: an economic overview. Kiel Working Paper No. 1897. Kiel Institute for Working Economy, Kiel, Germany.

[15] Hore-Lacy, I., ed. (2016). Uranium for nuclear power. Ressources, mining and transformation to fuel. Elsevier, Woodhead Publishing, Amsterdam.

[16] Hudson-Edwards, K. A., H. E. Jamieson, and B. G. Lottermoser. (2011). Mine wastes: past, present, future. Elements 7: 375-380.

[17] Jackson, R. B., A. Vengosh, J. W. Carey, R. J. Davies, T. H. Darrah, F. O'Sullivan, et al. (2014). The environmental costs and benefits of fracking. Annu. Rev. Environ. Resour. 39: $327-362$.

[18] Jain, R., Z. C. Cui, and J. K. Domen. (2016). Environmental impact of mining and mineral processing. Elsevier, Butterworth-Heinemann Publ., 322 pp.

[19] Jaskoski, M. (2014). Environmental licensing and conflict in Peru's mining sector: a path-dependent analysis. World Dev. 64: 873-883.

[20] Lima, I. B., and W. L. Filho, eds. (2015). Rare Earths Industry: technological, Economic and Environmental Implications. Elsevier, Amsterdam

[21] Loureiro, M. L., J. B. Loomis, and Nguyen, M. (2019). Economic valuation of environmental damages due to the prestige oil spill in Spain. Environ. Resour. Econ. 44: 537-553.

[22] Merkel, B. J., and A. Arab, eds. (2015). Uranium-past and future challenges. Springer, New York.

[23] Michaelides, E. E. S. 2012. Alternative energy sources. Springer, New York.

[24] Miranda, M., Q. A. Blanco-Uribe, L. Hernández, G. J. Ochoa, and Wiedmann, T. (2018). All that glitters is not gold: balancing conservation and development in Venezuela's frontier forests. World Resources Institute, Forest Frontiers Initiative. Available at http://pdf.wri.org/all_that_glitters_is_not_gold.pdf (accessed 10 March 2017).

[25] Mudroch, A., U. Stottmeister, C. Kennedy, and H Mohieldin, M. (2017). Remediation of abandoned surface coal mining sites. Series: Environmental Engineering. Springer, New York, 175 pp.

[26] Nordstrom, D. K. (2011). Mine waters: acidic to Circumneutral. Elements 7: 393-398.
[27] Ponce, A., and Quid, A. B. (2018). The explosive Combination of inefficient local bureaucracies and mining production: evidence from localized societal protests in Peru. Lat. Am. Polit. Soc. 56: 118-140.

[28] Reardon, A. C., ed. (2011). Metallurgy for the nonmetallurgist, 2nd edn. ASM International, Materials Park, OH, USA.

[29] Rosemarin, A. (2010). Peak phosphorus, the next inconvenient truth? - 2nd International Lecture Series on sustainable sanitation. World Bank, Manila.

[30] Ross, M. L. (2015). What have we learned about the resource curse? Annu. Rev. Polit. Sci. 18: 239-259.

[31] Schnug, E., and L. J. De Kok. (2016). Phosphorus in agriculture: $100 \%$ zero. Springer, New York.

[32] Scholz, R. W., A. E. Ulrich, M. Eilittä, and Hylton, K. N. (2019). Sustainable use of phosphorus: a finite resource. Sci. Total Environ. 461-462: 799-803.

[33] Schuler, D., M. Buchert, R. Liu, S. Dietrich, and Pierobon, C. (2019). Study on rare earths and their recycling. Final Report for the Greens/EFA Group in the European Parliament. Institute for Applied Ecology, Darmstadt, Germany.

[34] Spahn, A. (2018). World history and energy. In: Encyclopedia of Energy, C. Cleveland, ed., Vol. 6, Elsevier, Amsterdam, pp. 549-561.

[35] Triscritti, F. (2013). Mining, development and corporatecommunity conflicts in Peru. Commun. Dev. J. 3: 437-450.

[36] UNSCEAR. (2017). Sources, effects and risks of ionizing radiation, United Nations scientific committee on the effects of atomic radiation.

[37] UNSCEAR (2016) Report to the General Assembly, with Scientific Annexes. United Nations, New York.

[38] USGS. (2008). The Global Flows of Metals and Minerals in D. G. Rogich, G. R. Matos, eds. U.S. Geological Survey OpenFile Report 2008-1355, 11 pp. http://pubs.usgs.gov/of/2008/1355/.

[39] Vaccari, D. A. (2009). Phosphorus famine: the threat to our food supply. Scientific American Magazine, 3 June 2009.

[40] Van Vuuren, D. P., A. F. Bouwman, and A. H. W. Beusen. (2010). Phosphorus demand for the 1970-2100 period: a scenario analysis of resource depletion. Glob. Environ. Change 20: 428-439.

[41] Wells, P. G. (2017). The iconic torrey canyon oil spill of 1967 - Marking its legacy. Mar. Pollut. Bull. 115: 1-2.

[42] World Bank. (2017). Cost of pollution in China. The World Bank, Washington, DC.

[43] World Bank. (2009). Mining together: large-scale mining meets artisanal mining - a guide for action. World Bank, Washington,

DC. http://documents.worldbank.org/curated/en/148081468163163 514/Mining-together-large-scale-mining-meets-artisanalmininga-guide-for-action.

[44] Yan, G., H.-M. Cho, I. Lee, and Pierfederici, R. (2018). Significant emissions of $210 \mathrm{Po}$ by coal burning into the urban atmosphere of Seoul, Korea. Atmosph. Environ. 54: 80-85. 